\title{
Phytochemical analysis of Eucalyptus camaldulensis leaves extracts and testing its antimicrobial and schistosomicidal activities
}

\author{
Mosad A. Ghareeb ${ }^{1 *}$ (D, Mohamed R. Habib², Hanan S. Mossalem² and Mohamed S. Abdel-Aziz ${ }^{3}$
}

\begin{abstract}
Background: The emerging evolution of antibiotic and anthelmintic resistance and inefficiency of some synthetic drugs elicit the need to investigate new drug sources. In this context, Eucalyptus camaldulensis is an evergreen tree that has been widely used in traditional medicine for the treatment of various health disorders.

Results: Organic solvent extracts from Eucalyptus camaldulensis leaves were assessed for their antimicrobial activity. Among these extracts, ethyl acetate (EtOAc) and water extracts showed the highest antimicrobial activity against Staphylococcus aureus, Pseudomonas aeruginosa, Candida albicans, and Aspergillus niger. EtOAc extract was further subjected to vacuum liquid chromatography (VLC) technique for the isolation of its polyphenolic ingredients. VLC yielded 13 fractions (1-13) that were assayed for their antimicrobial activities. Six of these fractions, namely 4, 5, 6, 7, 8 , and 9, showed antimicrobial activity against all the tested microbes except the fungus Aspergillus niger. Fractions 5 and 6 having considerably the highest antimicrobial activity with inhibition zones ranged from 5 to $14 \mathrm{~mm}$. Moreover, fraction 5 was tested as a larvicidal agent against miracidia and cercariae of Schistosoma mansoni. At concentration of $200 \mathrm{mg} / \mathrm{L}$, the mortality rates of miracidia and cercariae of Schistosoma mansoni were 30\%, 20\%, $50 \%, 40 \%, 80 \%, 20 \%$, and 100\%, 80\% at 5, 10, 15, and 20 min, respectively. Chromatographic isolation of the EtOAc extract led to identification of six compounds: gallic acid (1), taxifolin (2), methyl gallate (3), quercetin (4), luteolin (5), and hesperidin (6).
\end{abstract}

Conclusions: Ethyl acetate extract from Eucalyptus camaldulensis leaves showed a potent antimicrobial and antischistosomal activity. This activity may be attributed to the six phenolic compounds identified through structure elucidation. Thus, these compounds can be good candidates for treatment of microbes and for the control of schistosomiasis.

Keywords: Eucalyptus camaldulensis, VLC, Polyphenolics, Antimicrobial, Antischistosomal, Miracidia, Cercariae

\section{Background}

Eucalyptus is the most important genera in the botanical family Myrtaceae; it is widely distributed in different regions around the world, with more than 800 species (Hassine et al. 2013). Eucalyptus camaldulensis Dehnh, commonly known as the river red gum, is endemic in Australia (Singab et al. 2011). Leaves of E. camaldulensis are known to possess

\footnotetext{
* Correspondence: m.ghareeb@tbri.gov.eg

'Department of Medicinal Chemistry, Theodor Bilharz Research Institute,

Kornish El-Nile St., Warrak El-Hader, Imbaba, Giza 12411, Egypt

Full list of author information is available at the end of the article
}

several biological and pharmacological activities, including antioxidant (Singab et al. 2011), cytotoxic (Singab et al. 2011; Daniela et al. 2007; Meshkani et al. 2014), antimicrobial (Ghalem and Mohamed 2008), larvicidal (Medhi et al. 2010), pesticidal (Batish et al. 2008), and anti-dermatophytes (Falahati et al. 2005). Literature survey revealed the isolation and identification of some chemical ingredients from different parts of E. camaldulensis including eucalyptanoic acid (Begum et al. 2002), flavonoids (Abd-Alla et al. 1980), acylated pentacyclic triterpenoids (Siddiqui et al. 1997), and essential oils (Ghalem and Mohamed 2014; Gakuubi 2016). 
Medicinal plants have a long history in the treatment of various ailments and diseases especially infectious diseases due to their therapeutic benefits (Saad et al. 2017). The microbial resistance to the existence antibiotics is well known, so it is very important to search for alternative antimicrobial agents from natural source like plants or herbs to overcome this challenge (Ghareeb et al. 2015).

Various medicinal plants were proven efficient drug candidates to control tropical parasitic diseases such as schistosomiasis (El-Sayed et al. 2011a; de Moraes 2015; El-Sayed et al. 2011b). Although praziquantel, the currently used drug for human infections of schistosomiasis, is safe and effective, it has some problem such as the emerging resistance to some laboratory strains of Schistosoma (Fallon and Doenhoff 1994; Doenhoff et al. 2009). Similarly, the chemical molluscicide used to control the snail's intermediate hosts of schistosomiasis is cost-effective and has some environmental side effects (King and Bertsch 2015). In this context, some plants are widely tested as molluscicides against snails due to their toxic effects. Other plants are not toxic to snails, but due to their powerful antioxidant capacity, they were used as supplementary antioxidants to control schsitosome infection within snails (Mossalem et al. 2017). Moreover, E. camaldulensis itself was shown to reduce the outcome of S. mansoni infection in Biomphalaria alexandrina (Mossalem et al. 2018).

Numerous studies have showed that ordinary antioxidants in plants are intimately linked to their bio functionalities such as the reduction of chronic diseases and inhibition of pathogenic bacteria growth, which are often associated with the termination of free radical proliferation in biological systems (Covacci et al. 2001; Ghareeb et al. 2018a; Sobeh et al. 2018). Therefore, the aim of the current study was to evaluate the in vitro antimicrobial and antischistosomal activity of E. camaldulensis leaves' extracts as well as the chromatographic isolation of the ethyl acetate extract followed by the structural elucidation of pure isolated compounds.

\section{Methods}

Collection of plant material, extraction, and fractionation The fresh leaves of Eucalyptus camaldulensis Dehnh were collected from Giza governorate during June, 2016. The identification and authentication of the plant was carried out by Dr. Therese Labib, Department of Flora and Taxonomy, El-Orman Botanical Garden, Giza, Egypt. A voucher specimen (No. E25/4/3) is kept in the herbarium of the garden. Details of extraction of E. camaldulensis leaves using organic solvents and testing the free radical scavenging activity of the obtained extracts are described in Mossalem et al. (Mossalem et al. 2018).

Instruments, chemicals, and reagents

The ${ }^{1} \mathrm{H}$ and ${ }^{13} \mathrm{C}-\mathrm{NMR}$ analyses were recorded on BRUKER 400 (400 and $100 \mathrm{MHz}$ for ${ }^{1} \mathrm{H}$ and ${ }^{13} \mathrm{C}-\mathrm{NMR}$, respectively). For column chromatography, we used the following chemicals and materials: Sephadex LH-20 (Pharmacia Fine Chemicals), Silica gel (60-200 mesh) (S.D. fine-CHEM Ltd.) and Whatmann No. 1 sheet filter papers (Whatmann Ltd., Maidstone, Kent, England). Thin layer chromatography with aluminum sheet $(20 \times$ 20) percolated with silica gel $60 \mathrm{~F}_{254}$ was obtained from E. Mark (Darmstadt, Germany).

\section{Vacuum liquid chromatography (VLC) of the ethyl acetate extract}

The ethyl acetate extract (10 g) was subjected to vacuum liquid chromatography (VLC) using silica gel GF254 (300 g) as stationary phase and eluted via gradient mix elution system with increasing polarity including $n$-hexane, $n$-hexane/EtOAc (80:20, 60:40, 40:60, and 20:80; $v /$ v), EtOAc, $\mathrm{CH}_{2} \mathrm{Cl}_{2}, \mathrm{CH}_{2} \mathrm{Cl}_{2} /$ methanol (MeOH) (80:20, $60: 40,40: 60$, and 20:80; v/v), $\mathrm{MeOH}$ and acetone to afford 13 fractions (Table 1). The major fraction 4 (0.3 g) was eluted with $n$-hexane/EtOAc (40:60) and then rechromatographed for further purification using Sephadex LH-20 sub-column initially eluted with 5\% $\mathrm{MeOH}$, and the polarity was increased with different ratios of $\mathrm{MeOH}$ until reaching $100 \% \mathrm{MeOH}$. The resulting fractions were combined on the basis of paper chromatography (PC) eluted by two common eluents, $15 \%$ acetic acid $(15 \% \mathrm{AcOH})$ and BAW (n-butanol to acetic acid to water; $4: 1: 5 ; v / v / v /$ upper layer) to afford compound 1 $(10 \mathrm{mg})$. Similarly, another major fraction 5 (0.5 g) was eluted with $n$-hexane/EtOAc (20:80) and then rechromatographed using Sephadex LH-20 sub-column to afford compound $2(15 \mathrm{mg})$. Fraction 6 (0.5 g) was eluted with EtOAc then rechromatographed using Sephadex LH-20 sub-column to afford compound $3(10 \mathrm{mg})$. Fraction 7

Table 1 Vacuum liquid chromatography (VLC) of the ethyl acetate extract

\begin{tabular}{llll}
\hline Fraction & Elution system & $\%$ or $v / v$ & Yield $(\mathrm{g})$ \\
\hline 1 & $n$-hexane & $100 \%$ & 0.0000 \\
2 & $n$-hexane/EtOAc & $80: 20$ & 0.2037 \\
3 & $n$-hexane/EtOAc & $60: 40$ & 0.2987 \\
4 & $n$-hexane/EtOAc & $40: 60$ & 0.3505 \\
5 & $n$-hexane/EtOAc & $20: 80$ & 0.5470 \\
6 & $\mathrm{EtOAc}$ & $100 \%$ & 0.5210 \\
7 & $\mathrm{CH}_{2} \mathrm{Cl}_{2}$ & $100 \%$ & 0.20 \\
8 & $\mathrm{CH}_{2} \mathrm{Cl}_{2} / \mathrm{MeOH}$ & $80: 20$ & 2.7269 \\
9 & $\mathrm{CH}_{2} \mathrm{Cl}_{2} / \mathrm{MeOH}$ & $60: 40$ & 2.2427 \\
10 & $\mathrm{CH}_{2} \mathrm{Cl} / \mathrm{MeOH}$ & $40: 60$ & 0.2636 \\
11 & $\mathrm{CH}_{2} \mathrm{Cl}_{2} / \mathrm{MeOH}$ & $20: 80$ & 0.0888 \\
12 & $\mathrm{MeOH}_{13}$ & $100 \%$ & 0.0461 \\
\hline
\end{tabular}


(0.15 g) was eluted with $\mathrm{CH}_{2} \mathrm{Cl}_{2}$ then rechromatographed using Sephadex LH-20 sub-column to afford compound $4(10 \mathrm{mg})$. Fraction 8 ( $2.5 \mathrm{~g})$ was eluted with $\mathrm{CH}_{2} \mathrm{Cl}_{2} / \mathrm{MeOH}$ (80:20) then rechromatographed using Sephadex LH-20 sub-column to afford compound 5 $(10 \mathrm{mg})$. Finally, fraction $9(2.20 \mathrm{~g})$ was eluted with $\mathrm{CH}_{2} \mathrm{Cl}_{2} / \mathrm{MeOH}$ (60:40) then rechromatographed using Sephadex LH-20 sub-column to afford compound 6 (10 mg).

\section{Antimicrobial activity}

Disc agar plate method has been recognized to assess the antimicrobial activities of organic solvent extracts from $E$. camaldulensis as well as the selected ethyl acetate VLC fractions (El-Neekety et al. 2016). Four different test microbes, Staphylococcus aureus (G+ve bacterium), Pseudomonas aeruginosa (G-ve bacterium), Candida albicans (yeast), and Aspergillus niger (fungus), were selected to evaluate the antimicrobial activities. The bacterial and yeast test microbes were grown on a nutrient agar medium. On the other hand, the fungal test microbe was cultivated on Czapek-Dox medium. The culture of each test microbe was diluted by distilled water (sterilized) to $10^{7}$ to $10^{8}$ colony-forming units (CFU)/mL then $1 \mathrm{~mL}$ of each was used to inoculate 1-L Erlenmeyer flask containing $250 \mathrm{~mL}$ of solidified agar media. These media were put on the previously sterilized petri dishes (10 $\mathrm{cm}$ diameter having $25 \mathrm{~mL}$ of solidified media). Filter paper discs (5 $\mathrm{mm} \varnothing$, Whatmann No. 1 filter paper) loaded with $0.2 \mathrm{mg}$ of each extract. The discs were dried at room temperature under sterilized conditions. The paper discs were placed on agar plates seeded with test microbes and incubated for $24 \mathrm{~h}$, at the appropriate temperature of each test organism. Antimicrobial activities were recorded as the diameter of the clear zones (including the disc itself) that appeared around the discs (Hathout et al. 2016; Madkour et al. 2017).

\section{Effect of E. camaldulensis extracts against Schistosoma mansoni larvae}

Miracidia and cercariae of $S$. mansoni were obtained from Schsitosome Biological Supply Center (SBSC), Theodor Bilharz Research Institute. The selected concentration was $200 \mathrm{mg} / \mathrm{L}$ (Mossalem et al. 2018). A double concentration of fraction $5 n$-hexane/EtOAc (20: $80 \mathrm{v} / \mathrm{v}$ ) was prepared in $5 \mathrm{ml}$ volume of water. Then, it was added to a petri dish containing 50 fresh hatched miracidia in $5 \mathrm{~mL}$ of water (final volume is $10 \mathrm{~mL}$ ). Another $10 \mathrm{~mL}$ dechlorinated tap water containing 50 fresh hatched miracidia served as control (Mohamed et al. 2012). Following 5, 10, 15, 20, 25, and $30 \mathrm{~min}$, the petri dishes were examined under dissecting microscope and mortalities in miracidia were recorded (the larvae were considered dead when they stopped movement completely for $1 \mathrm{~min}$ ) (Mahmoud and Ibrahim 2011). The same experiment was repeated with cercariae. Percentages of dead miracidia and cercariae were compared by Chi-square test (Mohamed et al. 2012).

\section{Results}

In vitro antimicrobial activity

The in vitro antimicrobial activity of organic solvent leaf extracts of E. camaldulensis was evaluated via disc agar method against four pathogenic strains of microbes, Staphylococcus aureus (G+ve bacteria), Pseudomonas aeruginosa (G-ve bacteria), Candida albicans (yeast), and Aspergillus niger (fungus), and compared to Neomycin and Cyclohexamide as standard antibiotics. The antimicrobial activities of the tested extracts were expressed in clear zone of inhibition ( $\mathrm{mm})$. The results in Table 2 and Fig. 1 revealed that water extract showed the highest inhibition zones $(13,11,11$, and $9 \mathrm{~mm}$, for $S$. aureus, $P$. aeruginosa, $C$. albicans, and $A$. niger, respectively. Ethyl acetate extract exhibited antimicrobial activity very close to the water extract with inhibition zones of $11,10,10$, and $8 \mathrm{~mm}$ for $S$. aureus, P. aeruginosa, C. albicans, and $A$. niger, respectively. The other solvent extracts showed antimicrobial activities according to the following order: $n$-butanol > dichloromethane > petroleum ether $>90 \%$ methanol. Further fractionation of ethyl acetate extract using VLC yielded 13 fractions, six of them (fractions 4, $5,6,7,8$, and 9) exhibited antimicrobial activities against all test microbes except $A$. niger. While the fractions ( 1 , $2,3,10,11,12$, and 13) are inferior in the antimicrobial activity, fraction 5 showed the highest antimicrobial activity among the fractions tested. Inhibition zones were 15,13 , and $14 \mathrm{~mm}$ against $S$. aureus, $P$. aeruginosa, and C. albicans, respectively (Table 3 and Fig. 2).

Table $\mathbf{2}$ In vitro antimicrobial activity of organic solvent extracts of E. camaldulensis leaves

\begin{tabular}{|c|c|c|c|c|}
\hline \multirow[t]{2}{*}{ Solvent extracts } & \multicolumn{4}{|c|}{ Clear zone ( $\mathrm{mm})$} \\
\hline & $\begin{array}{l}\text { Staphylococcus } \\
\text { aureus }\end{array}$ & $\begin{array}{l}\text { Pseudomonas } \\
\text { aeruginosa }\end{array}$ & $\begin{array}{l}\text { Candida } \\
\text { albicans }\end{array}$ & $\begin{array}{l}\text { Aspergillus } \\
\text { niger }\end{array}$ \\
\hline 1. $90 \% \mathrm{MeOH}$ & - & 8 & - & - \\
\hline 2. EtOAc & 11 & 10 & 10 & 8 \\
\hline 3. Water & 13 & 11 & 11 & 9 \\
\hline $\begin{array}{l}4 . \\
\text { Dichloromethane }\end{array}$ & 6 & 6 & - & - \\
\hline 5. n-Butanol & 8 & 8 & 7 & 6 \\
\hline 6. Petroleum ether & - & - & 6 & 9 \\
\hline \multicolumn{5}{|l|}{ Antibiotic } \\
\hline Neomycin ${ }^{1}$ & 17 & 20 & 21 & - \\
\hline Cyclohexamide $^{2}$ & - & - & - & 25 \\
\hline
\end{tabular}

${ }^{1}$ Neomycin was used at 200 microgram per disc

${ }^{2}$ Cyclohexamidewas used at 200 microgram per disc 

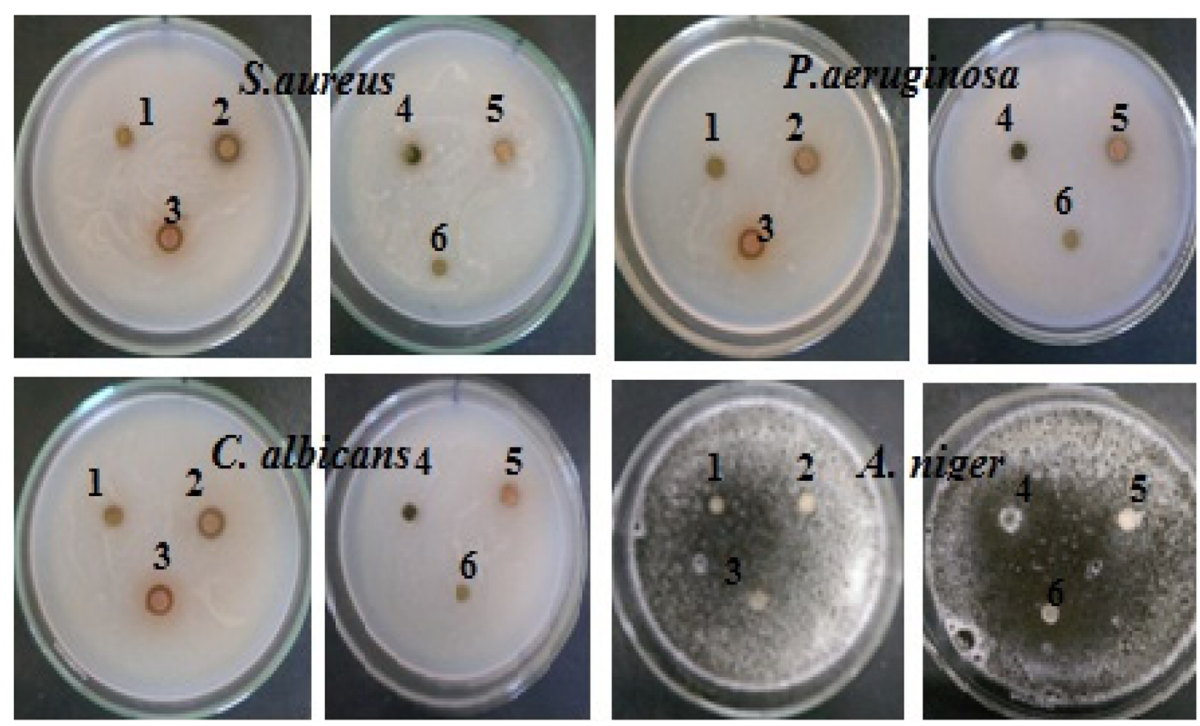

Fig. 1 The antimicrobial activity of organic solvent fractions from methanolic extract of $E$. camaldulensis leaves

\section{Miracidicidal and cercaricidal effect}

Observation of $S$. mansoni miracidial and cercarial mortalities following exposure to $200 \mathrm{mg} / \mathrm{L}$ of fraction 5 $n$-hexane/EtOAc $(20: 80 \mathrm{v} / v)$, isolated from ethyl acetate extract of $E$. camaldulensis leaves by VLC technique, showed a gradual increase in mortalities rate with increasing exposure time. After a few minutes from exposure, both miracidia and cercariae exhibited

Table $\mathbf{3}$ In vitro antimicrobial activity of VLC fractions of ethyl acetate extract of $E$. camaldulensis leaves against different test microbes

\begin{tabular}{|c|c|c|c|c|}
\hline \multirow{2}{*}{$\begin{array}{l}\text { Ethyl } \\
\text { acetate VLC } \\
\text { fractions }\end{array}$} & \multicolumn{4}{|c|}{ Clear zone ( $\mathrm{mm})$} \\
\hline & $\begin{array}{l}\text { Staphylococcus } \\
\text { aureus }\end{array}$ & $\begin{array}{l}\text { Pseudomonas } \\
\text { aeruginosa }\end{array}$ & $\begin{array}{l}\text { Candida } \\
\text { albicans }\end{array}$ & $\begin{array}{l}\text { Aspergillus } \\
\text { niger }\end{array}$ \\
\hline \multicolumn{5}{|l|}{1} \\
\hline 2 & - & - & - & - \\
\hline 3 & - & - & 6 & - \\
\hline 4 & 8 & 8 & 12 & - \\
\hline 5 & 15 & 13 & 14 & - \\
\hline 6 & 11 & 12 & 11 & - \\
\hline 7 & 7 & 7 & 6 & - \\
\hline 8 & 9 & 10 & 8 & - \\
\hline 9 & 9 & 10 & 10 & - \\
\hline 10 & - & - & - & - \\
\hline 11 & - & - & - & - \\
\hline 12 & - & - & - & - \\
\hline 13 & - & - & - & - \\
\hline \multicolumn{5}{|l|}{ Antibiotic } \\
\hline Neomycin & & 19 & 21 & - \\
\hline
\end{tabular}

morphological changes started by inactivation of their internal parts and ended via complete death with extended exposure time. Mortalities rates of miracidia were $30 \%, 50 \%, 80 \%$, and $100 \%$ after $5,10,15$, and $20 \mathrm{~min}$ of continuous exposure to $200 \mathrm{mg} / \mathrm{L}$ of the fraction, respectively. As indicated in Table 4 by $20 \mathrm{~min}$ of exposure, all the miracidia were found dead. Moreover, cercariae exhibited a similar pattern of gradual increase in mortality rate with prolonged exposure time. Complete death $(100 \%)$ of cercariae was recorded after $30 \mathrm{~min}$ of continuous exposure.

\section{Chromatographic isolation of the ethyl acetate extract}

Six phenolic compounds were isolated from the EtOAc extract of E. camaldulensis. Based on ${ }^{1} \mathrm{H}-\mathrm{NMR}$ spectra, chromatographic data, and available data in the literature; their chemical structures were elucidated as gallic acid (1), taxifolin (2), methyl gallate (3), quercetin (4), luteolin (5), and hesperidin (6) (Fig. 3).

\section{Discussion}

\section{In vitro antimicrobial activity}

Microbial infections still have a great public issue, and there is a dramatic increase in the microbial resistance to the existence antimicrobial agents (Collins and Lyne 1985). Most medicinal plant extracts showed a synergistic antimicrobial activity (Co-activity), which may be attributed to the collaborative action between their mixed constituents like flavonoids, anthraquinones, coumarins, and phenolic acids (Murugan et al. 2013).

Reviewing the literature revealed that the antibacterial activity of three solvent extracts (methanol, dichloromethane, and petroleum ether) of E. camaldulensis 

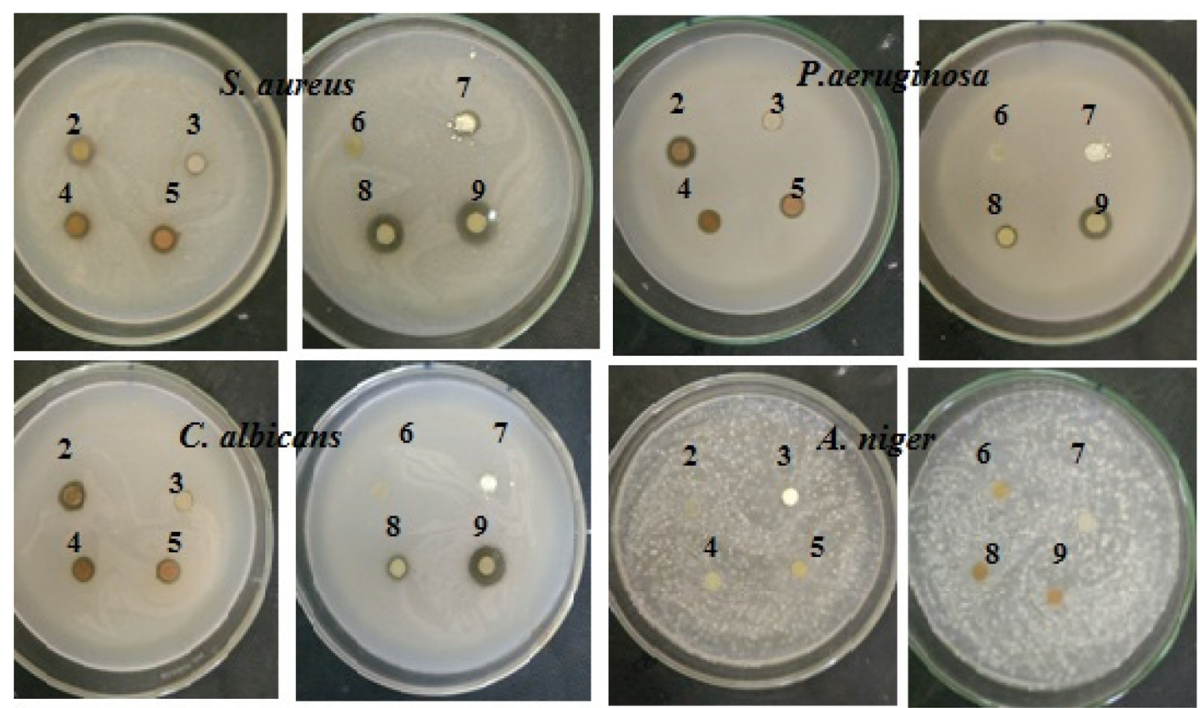

Fig. 2 The antimicrobial activity of VLC fractions from ethyl acetate extract of E. camaldulensis leaves

leaves growing in Nigeria was evaluated against six microbial species, namely Klebsiella spp., Salmonella typhi, Yersinia enterocolitica, Pseudomonas aeruginosa, Staphylococcus aureus, and Bacillus subtilis; for the methanolic extract, it showed strong activity with inhibition zones of $14,16,14,15,15$, and $16 \mathrm{~mm}$ while for dichloromethane were $15,15,13,13,14$, and $14 \mathrm{~mm}$, respectively, for the abovementioned species, and there is no any activity was recorded with petroleum ether (Saad et al. 2017). Moreover, the in vitro antimicrobial activity of the Nigerian E. camaldulensis was evaluated against six strains of Helicobacter pylori (Adeniyi et al. 2009). Previous studies stated that polyphenolic compounds are responsible for the antimicrobial activity of the plant extracts (Funatogawa et al. 2004; Buzzini et al. 2008; Min et al. 2008). To sum up, E. camaldulensis exhibited noticeable antimicrobial potentials which may be return to their unique chemical profile.

Table 4 Schistosoma miracidial and cercarial mortality (\%) post exposure to $200 \mathrm{mg} / \mathrm{l}$ from VLC fraction (5)

\begin{tabular}{|c|c|c|c|c|}
\hline \multirow{2}{*}{$\begin{array}{l}\text { Exposure } \\
\text { time } \\
\text { (min) }\end{array}$} & \multicolumn{2}{|c|}{ Percentage of dead miracidia } & \multicolumn{2}{|c|}{ Percentage of dead cercariae } \\
\hline & Control & Exposed & Control & Exposed \\
\hline 5 & 0 & $30^{* * *}$ & 0 & $20^{* * *}$ \\
\hline 10 & 0 & $50^{* * *}$ & 0 & $40^{* * *}$ \\
\hline 15 & 0 & $80^{* * *}$ & 0 & $50^{* * *}$ \\
\hline 20 & 0 & $100^{* * *}$ & 0 & $80^{* * *}$ \\
\hline 25 & 0 & $100^{* * *}$ & 0 & $90^{* * *}$ \\
\hline 30 & 0 & $100^{* * *}$ & 0 & $100^{* * *}$ \\
\hline
\end{tabular}

***High significant at $p<0.001$ compared to control

\section{Toxicity to Schistosoma mansoni larvae}

Recently, there has been an interest to control schistosomes infection within snails rather than killing these intermediate hosts. This method has many advantages including maintenance of natural biodiversity in aquatic habitats and minimizing the environmental impacts related to application of chemical molluscicides (Mossalem et al. 2018). Plants rich with antioxidant molecules such as flavonoids and phenolic acids compounds are great targets for exogenous source of antioxidants that can maintain the balance between oxidative stress result from infection or other stressors and antioxidant system within organisms (Ghareeb et al. 2018b). Indeed, exposure of B. alexandrina to $90 \%$ defatted methanol extract from Punica granatum peels reduced the infection rates of snails with S. mansoni to $20 \%$ compared to $95 \%$ in infected unexposed snails (Mossalem et al. 2017). The same reduction in infection rate was obtained when snails exposed to ethyl acetate extract from E. camaldulensis leaves (Mossalem et al. 2018).

The results obtained from testing the larvicidal properties of fraction $5 n$-hexane/EtOAc isolated from ethyl acetate extract of $E$. camaldulensis leaves indicate that this fraction possesses a potent toxic effect to miracidia and cercariae of $S$. mansoni. At concentration of $200 \mathrm{mg} / \mathrm{L}$ from fraction $5 n$-hexane/EtOAc (20: $80 v / v)$, $100 \%$ mortality was recorded in miracidia and cercariae after 20 and $30 \mathrm{~min}$ of continuous exposure, respectively. Mossalem et al. (Mossalem et al. 2018) showed that ethyl acetate extract of $E$. camaldulensis possesses a powerful antioxidant activity and its administration to $B$. alexandrina snails prior and during pre-patent infection with $S$. mansoni resulted in a significant decrease in the 
<smiles>O=C(O)c1cc(O)c(O)c(O)c1</smiles>

(1) Gallic acid<smiles>COC1C=C(O)C(O)C=C1O</smiles>

(3) Methyl gallate<smiles>O=c1cc(-c2ccc(O)c(O)c2)oc2cc(O)cc(O)c12</smiles>

(5) Luteolin<smiles>O=C1c2c(O)cc(O)cc2O[C@H](c2ccc(O)c(O)c2)[C@@H]1O</smiles>

(2) Taxifolin<smiles>O=c1c(O)c(-c2ccc(Cl)c(O)c2)oc2cc(O)cc(O)c12</smiles>

(4) Quercetin<smiles>COc1ccc(C2CC(=O)c3c(O)cc(OC4OC(O)C(O)C(O)C(OC(C)C(O)C(O)C(C)O)C4O)cc3O2)cc1O</smiles>

(6) Hesperidin

Fig. 3 Chemical structures of the isolated compounds from the EtOAc extract of $E$. camaldulensis leaves

infection rate of snails and increased the survival rate of snails. In the same context, Al-Sayed et al. (Al-Sayed et al. 2014) reported a potent molluscicidal activity of $80 \%$ $\mathrm{MeOH}$ extract of $E$. globulus against $B$. alexandrina snails and also showed strong miracidicidal and cercaricidal activity ( $80 \%$ and $100 \%$ mortality, respectively) after a $2 \mathrm{~h}$ exposure. A wide range of plants were proven to have potent schistosomicidal prosperities. The seeds of Nigella sativa either in the form of powder or as extracts had larvicidal potency against S. mansoni miracidia and cercariae. $\mathrm{LC}_{50}$ values of this drug were 1 and $2 \mathrm{mg} / \mathrm{L}$ for miracidia and cercariae, respectively (Mansour et al. 2002; Mohamed et al. 2005). Studies of the effect of this plant on adult female and male worms suggested that the possible mechanism of its action against S. mansoni parasite is mediated by inhibiting important antioxidant enzymes in the worms (Mohamed et al. 2005). The plants Allium sativum and Allium cepa (powder) at concentrations of 50 and $100 \mathrm{mg} / \mathrm{L}$ caused $50 \%$ mortalities to $S$. mansoni miracidia, respectively (Mantawy et al. 2012). Also, tannins extracted from P. granatum at a concentration as low as $0.39 \mathrm{mg} / \mathrm{L}$ killed $100 \%$ of miracidia after $50-150 \mathrm{~min}$ and $50 \%$ of miracidia within 25.1-48.3 min (Abozeid et al. 2012).

Reports from other countries on testing different plant species for their larvicidal effect showed their potential as miracicidal and cercaricidal agents. Extracts of the leaves and fruits of Piper marginatum, Protium heptaphyllum, 
and Capsicum annuum from Brazil show a remarkable effect on the cercariae of $S$. mansoni. In the case of the oils of Piper marginatum and Capsicum annuum, 90-96\% of the cercariae of $S$. mansoni were killed within $15 \mathrm{~min}$ (Frischkorn et al. 1978). Moreover, extracts from Phytolacca dodecandra, Tamarindus indica, Acacia nilotica, Hibiscus sabdariffa and Tacca leontopetaloides from Sudan were toxic to miracidia and cercariae at concentration from 50 to $100 \mathrm{mg} / \mathrm{L}$ (Elsheikh et al. 1990).

The toxic effect of $n$-hexane/EtOAc fraction isolated from ethyl acetate extract of $E$. camaldulensis leaves may be exerted in a different mode of action that differ from the abovementioned plants. Since E. camaldulensis has a powerful antioxidant activity and is rich with bioactive molecules such as gallic acid, taxifolin, quercetin, luteolin, and hesperidin. One possible explanation is that exposure of the larvae to $200 \mathrm{mg} / \mathrm{L}$ of the fraction led to prod-oxidative acts or their interference with critical reactive oxygen species required for maintenance of cellular functions and physiological processes (Bouayed and Bohn 2010).

\section{Structural elucidation of the isolated compounds from the ethyl acetate extract}

Compound 1 was isolated as off white powder, m.p. 250-251 ${ }^{\circ} \mathrm{C}$. On paper chromatography (PC), it showed violet and deep violet spots under long and short UV light respectively as well as positive result with $\mathrm{FeCl}_{3} . R_{\mathrm{f}}$ values are $0.82(\mathrm{BAW})$ and $0.52(15 \% \mathrm{AcOH}) .{ }^{1} \mathrm{H}-\mathrm{NMR}$ spectra (400 MHZ, DMSO- $d_{6}$ ) showed a characteristic signal in the aromatic region for two identical aromatic protons at $\delta_{\mathrm{H}} 7.12 \mathrm{ppm}(2 \mathrm{H}, s, \mathrm{H}-2,6)$. The ${ }^{1} \mathrm{H}-\mathrm{NMR}$ and chemical data were in agreement with the reported data of 3,4,5-trihydroxybenzoic acid (gallic acid) (Chanwitheesuk et al. 2007).

Compound 2 was isolated as a yellow powder, m.p. $230-232{ }^{\circ} \mathrm{C}$. On PC, it showed a yellow fluorescence colored spot under long UV light turned to bright yellow with ammonia vapors. $R_{\mathrm{f}}$ values are PC 0.76 (BAW) and $0.07(15 \% \mathrm{AcOH})$, an indication of its nature as aglycone. ${ }^{1} \mathrm{H}-\mathrm{NMR}$ spectra (400 MHZ, DMSO- $d_{6}$ ) revealed the presence of three aromatic protons at B-ring was resonated at $\delta_{\mathrm{H}} 6.93\left(1 \mathrm{H}, \mathrm{d}, J=1.25 \mathrm{~Hz}, \mathrm{H}-2^{\prime}\right), 6.87(1 \mathrm{H}, \mathrm{dd}$, $\left.J=8.0,1.5 \mathrm{~Hz}, \mathrm{H}-6^{\prime}\right)$, and $6.80 \mathrm{ppm}(1 \mathrm{H}, \mathrm{d}, J=8.0 \mathrm{~Hz}$, H-5'). In addition, the presence of two meta-coupled protons at A-ring appeared at $\delta_{\mathrm{H}} 5.89(1 \mathrm{H}, \mathrm{d}, J=$ $1.25 \mathrm{~Hz}, \mathrm{H}-6)$ and $5.95 \mathrm{ppm}(1 \mathrm{H}, \mathrm{d}, J=1.25 \mathrm{~Hz}, \mathrm{H}-8)$, while the C-ring protons were resonated at $\delta_{\mathrm{H}} 4.89(1 \mathrm{H}$, $\mathrm{d}, J=11.5 \mathrm{~Hz}, \mathrm{H}-2)$ and $4.52 \mathrm{ppm}(1 \mathrm{H}, \mathrm{d}, J=11.5 \mathrm{~Hz}$, $\mathrm{H}-3)$. Based on the abovementioned spectral and chromatographic data, this compound could be identified as $3,5,7,3^{\prime}, 4^{\prime}$-pentahydroxy-flavanone (dihydroquercetin or taxifolin) (Kuspradini et al. 2009; Usman et al. 2016).

Compound 3 was isolated as off white powder, m.p. $200-202{ }^{\circ} \mathrm{C}$. On PC, it showed violet and deep violet spots under long and short UV light respectively. $R_{\mathrm{f}}$ values are 0.65 (BAW) and $0.70(15 \% \mathrm{AcOH})$ and positive results with $\mathrm{FeCl}_{3} .{ }^{1} \mathrm{H}-\mathrm{NMR}$ spectra (400 MHZ, DMSO- $d_{6}$ ) showed two sets of protons, the first one for the methoxy protons at $\delta_{\mathrm{H}} 3.78 \mathrm{ppm}\left(3 \mathrm{H}, \mathrm{s},-\mathrm{OCH}_{3}\right)$ and the second one for the two aromatic protons at $\delta_{\mathrm{H}} 7.14 \mathrm{ppm}(2 \mathrm{H}, s$, $\mathrm{H}-2,6)$. The ${ }^{1} \mathrm{H}-\mathrm{NMR}$ and chemical data were in agreement with that of methyl gallate (Choi et al. 2014).

Compound 4 was isolated as yellow powder, m.p. 311$313{ }^{\circ} \mathrm{C}$. On PC, it showed a yellow fluorescence colored spot under long UV light turned to bright yellow with ammonia vapors and green color with $\mathrm{FeCl}_{3}$. $R_{\mathrm{f}}$ values are 0.67 (BAW) and $0.07(15 \% \mathrm{AcOH})$ which were in the range of aglycones. ${ }^{1} \mathrm{H}-\mathrm{NMR}$ spectra $(400 \mathrm{MHZ}$, DMSO- $d_{6}$ ) showed different sets of resonances; two meta-coupled aromatic protons at A-ring were appeared at $\delta_{\mathrm{H}} 6.19(1 \mathrm{H}, \mathrm{d}, J=2.1 \mathrm{~Hz}, \mathrm{H}-6)$ and $6.41 \mathrm{ppm}(1 \mathrm{H}, \mathrm{d}, J$ $=2.1 \mathrm{~Hz}, \mathrm{H}-8)$. Three aromatic protons located at B-ring appeared at $\delta_{\mathrm{H}} 7.53\left(1 \mathrm{H}, \mathrm{d}, J=2.1 \mathrm{~Hz}, \mathrm{H}-2^{\prime}\right), 6.88(1 \mathrm{H}, \mathrm{d}$, $\left.J=8.0 \mathrm{~Hz}, \mathrm{H}-5^{\prime}\right)$, and $7.68 \mathrm{ppm}(1 \mathrm{H}, \mathrm{dd}, J=8.0,2.1 \mathrm{~Hz}$, H-6'). The most downfield protonappeared at $\delta_{\mathrm{H}}$ $12.5 \mathrm{ppm}(1 \mathrm{H}, \mathrm{s}, 5-\mathrm{OH})$. On the basis of ${ }^{1} \mathrm{H}-\mathrm{NMR}$ spectra and chromatic data, the compound could be identified as $5,7,3^{\prime}, 4^{\prime}$-flavon-3-ol (quercetin) (Huang et al. 2013).

Compound 5 was isolated as pale yellow powder, m.p. $320-322{ }^{\circ} \mathrm{C}$. On PC, it showed a dark purple florescence spot under long UV light. $R_{\mathrm{f}}$ values are $0.74(\mathrm{BAW})$ and $0.07(15 \% \mathrm{AcOH})$ which were in the range of aglycones. ${ }^{1} \mathrm{H}-\mathrm{NMR}$ spectra (400 MHZ, DMSO- $d_{6}$ ) showed different sets of aromatic protons; two meta-coupled protons at A-ring were appeared at $\delta_{\mathrm{H}} 6.25(1 \mathrm{H}, \mathrm{d}, J=2.1 \mathrm{~Hz}, \mathrm{H}-6)$ and $6.54 \mathrm{ppm}(1 \mathrm{H}, \mathrm{d}, J=2.1 \mathrm{~Hz}, \mathrm{H}-8)$. Another characteristic signal for proton in position 3 at $\mathrm{C}$-ring was appeared at $\delta_{\mathrm{H}} 6.73 \mathrm{ppm}(1 \mathrm{H}, s, \mathrm{H}-3)$. Moreover, a characteristic pattern for three protons at B-ring appeared at $\delta_{\mathrm{H}} 7.0(1 \mathrm{H}$, d, $\left.J=8.1 \mathrm{~Hz}, \mathrm{H}-5^{\prime}\right), 7.49\left(1 \mathrm{H}, \mathrm{dd}, J=8.0,2.1 \mathrm{~Hz}, \mathrm{H}-6^{\prime}\right)$, and $7.98 \mathrm{ppm}\left(1 \mathrm{H}, \mathrm{d}, J=2.1 \mathrm{~Hz}, \mathrm{H}-2^{\prime}\right)$. A most down field proton appeared at $\delta_{\mathrm{H}} 13.04 \mathrm{ppm}(1 \mathrm{H}, s, 5-\mathrm{OH})$ due to the effect of intermolecular hydrogen bond with adjacent carbonyl group at C-ring. Based on ${ }^{1} \mathrm{H}-\mathrm{NMR}$ and chromatographic data, the compound could be identified as $5,7,3^{\prime}, 4^{\prime}$-tetrahydroxy-flavone (luteolin) (Tshikalange et al. 2005; Sato et al. 2000).

Compound 6 was isolated as pale yellow powder, m.p. $250-252{ }^{\circ} \mathrm{C}$. On PC, it showed a yellowish green florescence spot under long UV light. $R_{\mathrm{f}}$ values are 0.56 (BAW) and $0.78(15 \% \mathrm{AcOH})$ indicating to its glycosidic nature. ${ }^{1} \mathrm{H}$-NMR spectra (400 MHZ, DMSO- $d_{6}$ ) revealed the presence of set of resonances were appeared at $\delta_{\mathrm{H}}$ $11.97 \mathrm{ppm}(1 \mathrm{H}$, br s, $5-\mathrm{OH})$ for the most downfield proton at position 5 at A-ring. Three aromatic protons of 1,3,4-trisubstituted B-ring were resonated at $\delta_{\mathrm{H}} 6.95$ $\left(1 \mathrm{H}, \mathrm{d}, J=2.1 \mathrm{~Hz}, \mathrm{H}-2^{\prime}\right), 6.85\left(1 \mathrm{H}, J=8.2 \mathrm{~Hz}, \mathrm{H}-5^{\prime}\right)$, and $6.81 \mathrm{ppm}\left(1 \mathrm{H}, \mathrm{dd}, J=8.2,2.1 \mathrm{~Hz}, \mathrm{H}-6^{\prime}\right)$. Also, two 
meta-coupled aromatic protons were resonated at $\delta_{\mathrm{H}}$ $6.13(1 \mathrm{H}, \mathrm{d}, J=2.1 \mathrm{~Hz}, \mathrm{H}-8)$ and $6.10 \mathrm{ppm}(1 \mathrm{H}, \mathrm{d}, J=$ $2.1 \mathrm{~Hz}, \mathrm{H}-6)$. C-ring protons appeared at $\delta_{\mathrm{H}} 5.35(1 \mathrm{H}$, dd, $J=11.2,5.1 \mathrm{~Hz}, \mathrm{H}-2), 3.15(1 \mathrm{H}, \mathrm{dd}, J=16.0,11.0 \mathrm{~Hz}$, $\mathrm{H}-3 \mathrm{a})$, and $2.51 \mathrm{ppm}(1 \mathrm{H}, \mathrm{dd}, J=16.0,5.0 \mathrm{~Hz}, \mathrm{H}-3 \mathrm{~b})$. Moreover, two characteristic anomeric protons of sugar moieties were located at $\delta_{\mathrm{H}} 5.07(1 \mathrm{H}, \mathrm{d}, J=7.5 \mathrm{~Hz}$, $\left.\mathrm{H}-1^{\prime \prime}\right)$ and $4.57 \mathrm{ppm}(1 \mathrm{H}$, br s, H-1"'). Methoxy and methyl protons were resonated at $\delta_{\mathrm{H}} 3.78(3 \mathrm{H}, \mathrm{s}$, 4- $\left.\mathrm{OCH}_{3}\right)$ and $1.09 \mathrm{ppm}(3 \mathrm{H}, \mathrm{d}, J=6.0 \mathrm{~Hz}, \mathrm{H}-6)$, respectively. Accordingly, on the basis of ${ }^{1} \mathrm{H}-\mathrm{NMR}$ spectral data and chromatographic features, the compound could be identified as $3^{\prime}, 5,7$-trihydroxy-4' -methoxyflavanone-7$O$-rutinoside (hesperidin or hesperetin 7-O-rutinoside) (Areias et al. 2001; Cuyckens et al. 2001).

\section{Conclusions}

Eucalyptus camaldulensis was considered as a prolific source for several biologically active metabolites. The ethyl acetate leaves' extract of this plant showed considerable antimicrobial and antischistosomal activity. Further fractionation by vacuum liquid chromatography (VLC) yielded 13 fractions from which 6 fractions exhibited antimicrobial activities. The most powerful antimicrobial fraction (5) also showed potent larvicidal activity against $S$. mansoni larvae. Chromatographic isolation of ethyl acetate extract led to identification of six phenolic compounds that could be responsible for the observed activity.

\section{Acknowledgements}

This research work was supported by funds from Research Projects Committee, Theodor Bilharz Research Institute, Giza, Egypt (No. 100M).

\section{Funding}

Not applicable.

\section{Availability of data and materials}

All the data obtained during the study are presented in this manuscript. Any further enquiries for additional information are available upon request from the corresponding author.

\section{Authors' contributions}

MAG, MRH, and HSM conceived and designed the study. MAG, MRH, HSM, and MSA performed the experiments. MAG, MRH, and MSA analyzed the data. MAG and MRH wrote the first draft, revised, and edited it. All authors read and approved the final manuscript.

\section{Ethics approval and consent to participate}

Ethical approval had been granted approval by the Ethics Committee of Theodor Bilharz Research Institute (TBRI).

\section{Consent for publication}

Not applicable.

\section{Competing interests}

The authors declare that they have no competing interest.

\section{Publisher's Note}

Springer Nature remains neutral with regard to jurisdictional claims in published maps and institutional affiliations.

\section{Author details}

'Department of Medicinal Chemistry, Theodor Bilharz Research Institute, Kornish El-Nile St., Warrak El-Hader, Imbaba, Giza 12411, Egypt. ${ }^{2}$ Medical Malacology Laboratory, Theodor Bilharz Research Institute, Giza 12411, Egypt. ${ }^{3}$ Microbial Chemistry Department, Genetic Engineering and Biotechnology Division, National Research Centre, El Behoos Street 33, Dokki-, Giza 12622, Egypt.

Received: 10 August 2018 Accepted: 8 October 2018

Published online: 26 October 2018

\section{References}

Abd-Alla MF, El-Negoumy SI, El-Lakany MH, Saleh NA (1980) Flavonoid glycosides and the chemosystematics of Eucalyptus camaldulensisis. Phytochemistry 19: 2629-2632

Abozeid K, Shohayeb M, Ismael A (2012) In vitro tests for efficacy of tannins extracted from pomegranate (Punica granatum) against Schistosoma mansoni miracidia. J Sci Technol 13:55-65

Adeniyi CBA, Lawal TO, Mahady GB (2009) In vitro susceptibility of Helicobacter pylori to extracts of Eucalyptus camaldulensis and Eucalyptus torelliana. Pharm Biol 47:99-102

Al-Sayed E, Hamid HA, Abu El-Einin HM (2014) Molluscicidal and antischistosomal activities of methanol extracts and isolated compounds from Eucalyptus globulus and Melaleuca styphelioides. Pharm Biol 52:698-705

Areias FM, Valentao P, Andrade PB, Ferreres F, Seabra RM (2001) Phenolic fingerprint of peppermint leaves. Food Chem 73:307-311

Batish DR, Singh HP, Kohli RK, Kaur S (2008) Eucalyptus essential oil as a natural pesticide. Forest Ecol Manag 256:2166-2174

Begum S, Sultana I, Siddiqui BS, Shaheen F, Gilani AH (2002) Structure and spasmolytic activity of eucalyptanoic acid from Eucalyptus camaldulensis var. obtusa and synthesis of its active derivative from oleanolic acid. J Nat Prod 65:1939-1941

Bouayed J, Bohn T (2010) Exogenous antioxidants—double-edged swords in cellular redox state: health beneficial effects at physiologic doses versus deleterious effects at high doses. Oxidative Med Cell Long 3:228-237

Buzzini P, Arapitsas P, Goretti M, Branda E, Turchetti B, Pinelli P, leri F, Romani A (2008) Antimicrobial and antiviral activity of hydrolysable tannins. Mini Rev Med Chem 8:1179-1187

Chanwitheesuk A, Teerawutgulrag A, Kilburn JD, Rakariyatham N (2007) Antimicrobial gallic acid from Caesalpinia mimosoides Lamk. Food Chem 100: 1044-1048

Choi J, Mun S, Chahar HS, Bharaj P, Kang O, Kim S, Shin D, Kwon D (2014) Methyl gallate from Galla rhois successfully controls clinical isolates of salmonella infection in both in vitro and in vivo systems. PLoS One 9:e102697

Collins CH, Lyne PM. Microbiological methods, $5^{\text {th }}$ edition, Butterworth \& co. pub. Ltd., London, UK \& Toronto, Canada, pp1-456, 1985

Covacci V, Torsello A, Palozza P, Sgambato A, Romano G, Boninsegna A, Cittadini A, Wolf FI (2001) DNA oxidative damage during differentiation of HL-60 human promyelocytic leukemia cells. Chem Res Toxicol 14:1492-1497

Cuyckens F, Rozenberg R, de Hoffmann E, Claeys M (2001) Structure characterization of flavonoid $O$-diglycosides by positive and negative nanoelectrospray ionization ion trap mass spectrometry. J Mass Spectromet 36: 1203-1210

Daniela A, Pichichero E, Canuti L, Cicconi R, Karou D, D'Arcangelo G, Canini A (2007) Identification of phenolic compounds from medicinal and melliferous plants and their cytotoxic activity in cancer cells. Caryologia 60:90-95

de Moraes J (2015) Natural products with antischistosomal activity. Future Med Chem 7:801-820

Doenhoff MJ, Hagan P, Cioli D, Southgate V, Pica-Mattoccia L, Botros S, Coles G, Tchuenté LT, Mbaye A, Engels D (2009) Praziquantel: its use in control of schistosomiasis in sub-Saharan Africa and current research needs. Parasitology 136:1825-1835

El-Neekety AA, Abdel-Aziz MS, Hathout AS, Hamed AA, Sabry BA, Ghareeb MA, Aly SE, Abdel-Wahhab MA (2016) Molecular identification of newly isolated non-toxigenic fungal strains having antiaflatoxigenic, antimicrobial and antioxidant activities. Der Pharm Chem 8:121-134

El-Sayed MM, Abdel-Hadi AM, Sabra AA, Mahmoud MA, El-Wakil EA, Ghareeb MA (2011a) Effect of Ficus sycomorus and Azadirachta indica extracts on liver state of mice infected with Schistosoma mansoni. J Egypt Soc Parasitol 41:77-88 
El-Sayed MM, Mahmoud MA, El-Nahas HA, El-Toumy SA, El-Wakil EA, Ghareeb MA (2011b) Chemical constituents, antischistosomal and antioxidant activities of the methanolic extract of Azadirachta indica. Egypt J Chem 54:99-113

Elsheikh SH, Bashir AK, Suliman SM, El Wassila M (1990) Toxicity of certain Sudanese plant extracts to cercariae and miracidia of Schistosoma mansoni. Inter J Crude Drug Res 28:241-245

Falahati M, Omidi Tabrizib N, Jahaniani F (2005) Anti dermatophyte activities of Eucalyptus camaldulensis in comparison with Griseofulvin. Iranian J Pharmacol Therap 4:80-83

Fallon PG, Doenhoff MJ (1994) Drug-resistant schistosomiasis: resistance to praziquantel and oxamniquine induced in Schistosoma mansoni in mice is drug specific. Amer J Trop Med Hyg 51:83-88

Frischkorn CGB, Frischkorn HE, Carrazzoni E (1978) Cercaricidal activity of some essential oils of plants from Brazil. Naturwissenschaften 65:480-483

Funatogawa K, Hayashi S, Shimomura H, Yoshida T, Hatano T, Ito H, Hirai Y (2004) Antibacterial activity of hydrolyzable tannins derived from medicinal plants against Helicobacter pylori. Microbiol Immunol 48:251-261

Gakuubi MM (2016) Steam distillation extraction and chemical composition of essential oils of Toddalia asiatica L. and Eucalyptus camaldulensis Dehnh. J Pharmacog Phytochem 5:99

Ghalem BR, Mohamed B (2008) Antibacterial activity of leaf essential oils of Eucalyptus globulus and Eucalyptus camaldulensis. Afr J Pharmacy Pharmacol 2:211-215

Ghalem BR, Mohamed B (2014) Antibacterial activity of essential oil of north west Algerian Eucalyptus camaldulensis against Escherichia coli and Staphylococcus aureus. J Coast Life Med 2:799-804

Ghareeb M, Saad A, Ahmed W, Refahy L, Nasr S (2018b) HPLC-DAD-ESI-MS/MS characterization of bioactive secondary metabolites from Strelitzia nicolai leaf extracts and their antioxidant and anticancer activities in vitro. Pharm Res 10(4):XX-XX

Ghareeb MA, Mohamed T, Saad AM, Refahy LA, Sobeh M, Wink M (2018a) HPLCDAD-ESI-MS/MS analysis of fruits from Firmiana simplex (L.) and evaluation of their antioxidant and antigenotoxic properties. J Pharm Pharmacol 70:133-142

Ghareeb MA, Refahy LA, Saad AM, Osman NS, Abdel-Aziz MS, El-Shazly MA, Mohamed AS (2015) In vitro antimicrobial activity of five Egyptian plant species. J Appl Pharm Sci. 5:45-49

Hassine DB, Abderrabbaba M, Cazaux S, Bouajila J (2013) Contribution to the chemical and biological study of Eucalyptus leaves extracts: effect on frying oil. J Med Bioeng 2:242-247

Hathout A, El-Nekeety A, Hamed A, Sabry B, Abdel-Aziz M, Ghareeb M, Aly S (2016) Novel Egyptian bacterial strains exhibiting antimicrobial and antiaflatoxigenic activity. J Appl Pharm Sci 6:001-010

Huang W, Wan C, Zhou S (2013) Quercetin-A flavonoid compound from Sarcopyramis bodinieri var delicate with potential apoptotic activity in HepG2 liver cancer cells. Trop J Pharmaceut 12:529-533

King CH, Bertsch D (2015) Historical perspective: snail control to prevent schistosomiasis. PLoS Negl Trop Dis 9:e0003657

Kuspradini H, Mitsunaga T, Ohashi H (2009) Antimicrobial activity against Streptococcus sobrinus and glucosyltransferase inhibitory activity of taxifolin and some flavanonol rhamnosides from kempas (Koompassia malaccensis) extracts. J Wood Sci 55:308-313

Madkour HMF, Ghareeb MA, Abdel-Aziz MS, Khalaf OM, Saad AM, El-Ziaty AK, Abdel-Mogib M (2017) Gas chromatography-mass spectrometry analysis, antimicrobial, anticancer and antioxidant activities of $n$-hexane and methylene chloride extracts of Senna italica. J Appl Pharm Sci. 7:023-032

Mahmoud MB, Ibrahim WL, Abou-El-Nour BM, El-Emam MA, Youssef AA. Biolological and biochemical parameters of Biomphalaria alexandrina snails to the plants Datura stramonium and Sesbania sesban as water suspentions of their dry powder. Pesticide Biochem Physiol 2011;99:96-104

Mansour SA, Ibrahim AM, Abdel-Hamid HF (2002) Botanical biocides 8. Impact of some plant extracts on Biomphalaria alexandrina snails and on Schistosoma mansoni miracidia and cercariae. Egypt J Schistosomiasis Infect Endem Dis 24:81-94

Mantawy MM, Aly HF, Zayed N, Fahmy ZH (2012) Antioxidant and schistosomicidal effect of Allium sativum and Allium cepa against Schistosoma mansoni different stages. Europ Rev Med Pharmacol Sci 16:69-80

Medhi SM, Reza S, Mahnaz K, Reza AM, Abbas H, Fatemeh M, Hassan V (2010) Phytochemistry and larvicidal activity of Eucalyptus camaldulensis against malaria vector, Anopheles stephensi. Asian Pacif J Trop Med 3:841-845

Meshkani N, Naghsh N, Ranjbar M (2014) Study of cytotoxic effects of ethanolic extract of Eucalyptus camaldulensis leaf on the cells k562 of human chronic
Myelogenous leukemia (CML) under in vitro conditions. Bull Environ Pharmacol Life Sci 3:186-190

Min BR, Pinchak WE, Merkel R, Walker S, Tomita G, Anderson RC (2008) Comparative antimicrobial activity of tannin extracts from perennial plants on mastitis pathogens. Sci Res Essay 3:66-73

Mohamed AM, El-Emam MA, Osman GY, Abdel Hamid H, Ali REM (2012) Biological and biochemical responses of infected Biomphalaria alexandrina snails with Schistosoma mansoni post exposure to the pesticides Basudin and selecron and the phytoalkaloid colchicine. J Evolutionary Bio Res 4:24-32

Mohamed AM, Metwally NM, Mahmoud SS (2005) Sativa seeds against Schistosoma mansoni different stages. Mem Inst Oswaldo Cruz 100:205-211

Mossalem HS, Ghareeb MA, Refahy LA, Mohamed AS (2017) Habib MR. GAS chromatography-mass spectrometry analysis and antioxidant activity of Punica granatum L. Peels and its role as immunostimulant against Schistosoma mansoni infection in Biomphalaria alexandrina. Asian J Pharmaceut. Clin Res 10:1-7

Mossalem HS, Habib MR, Ghareeb MA (2018) Control of infection of Biomphalaria alexandrina (Ehrenberg, 1831) with Schistosoma mansoni Sambon, 1907 using Eucalyptus camaldulensis. Folia Malacologica 26:1-11

Murugan T, Wins JA, Murugan M (2013) Antimicrobial activity and phytochemical constituents of leaf extracts of Cassia auriculata. Ind J Pharmaceut Sci 75:122

Saad AM, Mohammed MMD, Ghareeb MA, Ahmed WS, Farid MA (2017) Chemical composition and antimicrobial activity of the essential oil of the leaves of Cupressus macrocarpa Hartweg. Ex Gordon. J Appl Pharm Sci. 7:207-212

Sato Y, Suzaki S, Nishikawa T, Kihara M, Shibata H, Higuti T (2000) Phytochemical flavones isolated from Scutellaria barbata and antibacterial activity against methicillin-resistant Staphylococcus aureus. J Ethnopharmacol 72:483-488

Siddiqui BS, Begum S, Siddiqui S (1997) Isolation and structural elucidation of acylated pentacyclic triterpenoids from the leaves of Eucalyptus camaldulensis var. obtusa. Planta Med 63:47-50

Singab A, Ayoub N, Al-Sayed E, Martiskainen O, Sinkkonen J, Pihlaja K (2011) Phenolic constituents of Eucalyptus camaldulensis Dehnh, with potential antioxidant and cytotoxic activities. Rec Nat Prod 5:271-280

Sobeh M, Mahmoud MF, Hasan RA, Abdelfattah MA, Sabry OM, Ghareeb MA, ElShazly AM, Wink M (2018) Tannin-rich extracts from Lannea stuhlmannii and Lannea humilis (Anacardiaceae) exhibit hepatoprotective activities in vivo via enhancement of the anti-apoptotic protein Bcl-2. Sci Rep 8:9343

Tshikalange TE, Meyer JJM, Hussein AA (2005) Antimicrobial activity, toxicity and the isolation of a bioactive compound from plants used to treat sexually transmitted diseases. J Ethnopharmacol 96:515-519

Usman A, Thoss V, Nur-e-Alam M (2016) Isolation of taxifolin from Trichilia emetic whole seeds. Amer Scient Res J Eng Technol Sci 21:77-82

\section{Submit your manuscript to a SpringerOpen ${ }^{\circ}$ journal and benefit from:}

- Convenient online submission

- Rigorous peer review

- Open access: articles freely available online

High visibility within the field

- Retaining the copyright to your article

Submit your next manuscript at $\boldsymbol{\nabla}$ springeropen.com 